\title{
Developing An_Argument-Based Science Textbook for Junior High School Students to Improve Student's Critical Thinking Disposition and Critical Thinking Skill
}

\author{
I Ketut Sudiana ${ }^{1}$, I Wayan Redhana ${ }^{2}$ \\ 1,2,3 Universitas Pendidikan Ganesha, Indonesia
}

\section{A R T I C L E I N F O \\ Article history:}

Received 19

Desember 2017

Received in revised

form

6 Januari 2018

Accepted 12 Februari

2018

Available online 20

Februari 2018

\section{Keywords:}

Problem-Based Spot

Capturing Models,

Character

\begin{abstract}
A B S T R A C T
This study was aimed at producing an argument-based science teaching textbook for junior high school students to improve student's critical thinking disposition and critical thinking skill. This text book was produced by following Borg and Gall's (1983). Research and development model for three years. The first year research collected information (need analysis) used to design the draft of the product in the form of argument-based science text book for junior high school to improve student's disposition and critical thinking skill. The product of the first year research was in the form of a draft of the argument-based science textbook. The second year research tried out the argument-based science text book for junior high school in a limited scope, conducted in three SMP's in Bali province. This try-out used pretest-posttest one group design. The number of students involved in the second year research was 88 students. The result of the second year research showed that the argument-based science text book for junior high school could improve students' disposition skill by $21.48 \%$ and critical thinking skill by $57.22 \%$. The third year research tried out the argument-based science text book for junior high on a large scale in three SMP's in Bali province. The study used the pretest--posttest one group design. The number of students involved was 194 students, the control group and experiment group had 97 students respectively. As the comparison the text book entitled Buku Ajar IPA SMP Kurikulum 2013 was used. The data obtained from this third year research were in the form of scores for critical thinking disposition and critical thinking skill. These data were analyzed using multivariate covariance analysis at $5 \%$ level of significance. The large scale tries out in the third year was aimed at determining the effectiveness of the argument-based science teaching textbook for junior high school to improve student's disposition and critical thinking skill. The results showed that there was a significant effect of the argument-based science teaching text book for junior high school students to improve student's disposition and critical thinking skill on the student's critical thinking disposition and critical thinking skill both simultaneously and partially or individually. Based on the test of means difference, the argument-based science teaching text book for junior high school students was better than Buku Ajar IPA SMP Kurikulum 2013 in improving the student's critical thinking disposition and critical thinking skill both simultaneously and partially.
\end{abstract}

Copyright (c) Universitas Pendidikan Ganesha. All rights reserved.

\section{Introduction}

The twenty first century, the era that Richard Crawford called the Era of Human Capital (in Sidi, 2003) is the era of knowledge and technology development, especially communication technology. This development causes the increasingly more rapid flow of information and the opening of international market with its impact on free competition which is so tight in all expects of human life. In this competition quality human resources are badly needed. 
However, it is to be pitied that Indonesia's human development index (HDI) is at $124^{\text {th }}$ ranking from 187 countries (The Jakarta Post, 2011). This position lies below our neighboring countries in ASEAN, i.e., Singapore, Brunei, Malaysia, Thailand, and Philippines, that consecutively are at the $26^{\text {th }}, 33^{\text {rd }}, 61^{\text {st }}, 103^{\text {rd }}$, and 112nd (The Jakarta Post, 2011). This HDI was based on life expectancy, years of schooling, and per capita income. Similarly, according to the result of Trends International Mathematics Science Study (TIMSS) in science in 2011, Indonesia's students ranked $38^{\text {th }}$ from 45 countries that participated (International Association for the Evaluation of Educational Achievement [IAEAA], 2011). Meanwhile, in the forum of Program for International Student Assessment (PISA) for science literacy in 2012, Indonesia's students ranked $64^{\text {th }}$ from 65 countries that participated (Organization for Economic Cooperation and Development [OECD], 2012.

All of the problems above cannot be separated from textbooks, planning, process and evaluation of instructions that have been implemented by teachers so far. Science instruction cannot be separated from instructional media and textbooks used (Widiana, 2016). However, instructional media and material used in the field are not suitable with the expectation of the government in relation to integrated science materials (Puspitoroni, 2014). Science has to be taught using instruction that enables students to develop the abilities that they have and their own concepts by themselves. The basis of such instruction is called constructivistinstruction (Rizal, 2014).

Science is one of the important subjects taught to the students because through science the students will be able to possess a scientific attitude in solving problems that they are facing (Rusnadi, 2013). Science is expected to become a tool for the students to learn about themselves and the natural environment, and the prospect to develop science further in daily life (Susiani, 2013). According to Trisnani(2015) science has an important role in human development, both in the development of technology used to support human life and inapplying concepts. However, in reality, science learning achievement is still low. Textbook is one of the components that has an important role in developing student's reasoning. According to Sukerni (2014), a textbook has a systematic structure and sequence, which explains the instructional objectives to be achieved, motivates students to learn, anticipates students' difficulty by providing them with guidance to learn the book, giving a lot of exercises to the students, providing summaries, and in general, is oriented to the students individually (learner oriented). According to Soegiranto (2010), an instructional material is a material written by a teacher systematically which is used by the students in learning. Instructional materials can be presented in the form of print, nonpoint and can be audiovisual. Instructional materials written as a text book for the students can be in the form of modules (p.1).

Reasoning is in important aspect in developing critical thinking skill. The following is one of the patterns in reasoning or argument which is not so clear in Buku Ajar Kurikulum 2013. "Akibat kedudukan batu terhadap keadaan setimbang, batu mampu melakukan kerja atau memiliki energi. Energi yang diperoleh karena lokasi atau kedudukannya tersebut dinamakan energi potensial. Contoh lain, air dalam bendungan menyimpan energi potensial karena ketinggiannya." (Kemendikbud, 2013: 123). "As the effect ofthe position of a rock relative to a balanced condition, it can exert work or have energy. The energy obtained because of location is called potential energy. Another example is water in a dam that stores potential energy because of its height." (Kemendikbud, 2013: 123).

The pattern of reasoning (argument) in the paragraph is not clear. First, the choice of the word "akibat" (effect) is not appropriate since the word "akibat" (effect) is an indicator of a conclusion or claim, but in the paragraph above the word "akibat" (effect) is used for an indicator of premise. Secondly, the paragraph means that a rock has a potential energy because of its a position relative to a balanced condition, while water has potential energy because of its height. Does the position of the rock relative to the balanced condition mean height? This is not clear.

To solve the problem above and to prepare quality human resources in the future, education reformation needs to be done. The reformation covers the reformation in the presentation of science content in a textbook. This has to be oriented to developing student's critical thinking. Critical thinking disposition is a critical spirit, while critical thinking skill is a skill in thinking. In this study, an argumentbased science textbook for junior high school was developed through research and development. The use of argument in the book can challenge the students to analyze and evaluate premises and claims (conclusions) and to make a relation between a premise and a claim. In analyzing and evaluating this premise and claim, the students are guided with critical questions.

The results of study that are related to the development of students critical thinking skill have been reported by some researchers. The development of student's critical thinking skill has been done through an instruction based on problems and Socratic questions (Redhana, 2011). Meanwhile, effective student's critical thinking skill was developed through argument mapping (Lau \& Chan, 2009). According to Lau and Chan, to be able to to think critically, students have to be able to identify constructs and 
evaluate arguments. On the other hand, argument maps can improve the student's ability to articulate, understand, and communicate reasoning or arguments (van Gelder, 2003).

Based on the consideration of the importance of developing the student's critical thinking through argument mapping, a long term research with the aim of producing a software product for chemistry instruction based on argument map was conducted. To produce the research product some researches which have been conducted were "Application of argument mapping-based learning model to improve students critical thinking skill in thermochemistry topic" (Redhana, 2010a); "The development of argument-map-based-chemistry workbook of thermochemistry topic" (Redhana, 2010b); "The effectiveness of argument mapping-based chemistry workbook in improving student's critical thinking skill" (Redhana, 2011); "The effect of argument mapping-based learning model on chemistry learning achievement of senior high school students" (Redhana, 2012b); "The effect of argument mapping-based learning model on student's critical thinking and learning motivation " (Redhana, 2012c); and "The development of critical thinking skill test " (Sudria \& Redhana, 2013). In the present research" Developing an argument-based science textbook for junior high school to improve student's critical thinking disposition and critical thinking skill "and"Developing critical thinking disposition inventory "were conducted. In the future a research will be done on "Developing argument mapping-based chemistry learning software". Thus, the roadmap of researches to produce an argument mapping-based chemistry learning software can be summarized as in figure 1.1.

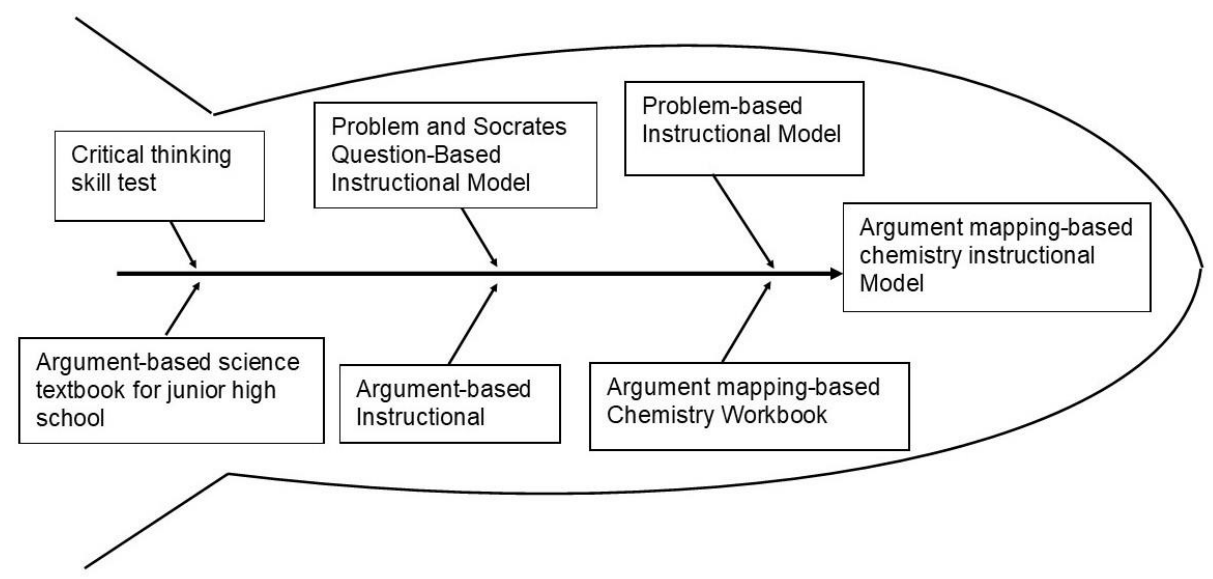

Figure 1. Roadmap of Researches on developing an argument mapping-based learning software.

By understanding the reasons that support the development of an effective and varied instruction, the writers were interested in conducting a research with the following title "Developing an argument-based science teaching for junior high school students to improve student's critical thinking disposition and critical thinking skill.

\section{Method}

This study used the research and development model. Research and development is a process to develop and validate educational products. The stages in research and development according to Borg and Gall (1989) consists of (1) doing a research and collecting information, (2) planning, (3) developing a product design, (4) doing a limited or the first try-out, (5) revising the main product on a large scale, (6) doing the main try-out, (7) revising the operational product, (8) doing an operational try-out, (9) revising final product, and (10) disseminating and implementing. In this research and development, the research activities were done until the stages of doing a try-out on a large scale and revising operational product.

The population and the sample depended on this stage of study. In the small scale research, the population consisted of science teachers and students in SMP's in Bali Province. By using cluster sampling, 30 SMP's were selected in Bali Province. For the sample of teachers, one science teacher was selected randomly from each school (from 30 SMP's that have been selected above). For the sample of students, one $7^{\text {th }}$ grade class was selected by using cluster sampling technique from each school (from 30 SMP's that have been selected). In the limited try-out, 3 SMP's were selected by using cluster sampling technique from SMP's in Bali Province, i.e., SMPN 1 Singaraja and SMPN 2 Singaraja and SMPN Sukasada. For the sample of students one $7^{\text {th }}$ grade class were selected using cluster sampling technique from each school (from three SMP's that have been selected above). Based on cluster sampling technique, class VIIA7 from SMPN 1 Singaraja with 22 students, class VIIA9 from SMPN 2 Singaraja with 30 students and class VIIA1 
from SMPN 4 Sukasada with 36 students were used as sample. In the try out on a large scale 3 SMP's were selected trough cluster sampling technique from SMP's in Bali Province. For the sample of students, two $7^{\text {th }}$ grade classes which were equivalent academically were selected with a lottery to determine control and experiment groups.

The procedure for the research and development of an argument-based science text book for junior high school in the first year followed the following steps: 1) Research and information collection: the activity done at this stage was collecting information from literature study and field study. The purpose of the literature study was to find concepts and theoretical foundation that strengthened the product that was developed. This literature study was done to collect research findings and information related to product development (argument-based science text book for junior high school) that had been planned. For this purpose the steps followed were : (1) analyzing the core competencies and basic competencies in science for junior high school to produce essential concepts, (2) describing the essential concepts to get a list of concepts to be analyzed, (3) to translate the basic competencies into the indicator of the attainment of competencies, (4) analyzing critical thinking disposition inventory, and (5) analyzing theories and research findings relevant to arguments and critical thinking disposition.

The field study was done to collect information related to the textbook developed. For this purpose the activities done in the study on limited scale were : (1) analyzing science textbooks used by the teachers and students, The analysis was focused on aspects of reasoning or argument and critical thinking; (2) analyzing instructional materials developed and used by science teachers; the analysis was focused on science materials and strategies implemented by the teachers; ;3) analyzing students characteristics ; and (4) analyzing supporting factors for the instruction at school.

2) Planning: Planning stage was done to develop the formulation of aims and design for the argument-based science textbook for junior high school. It was stated that the aim to be achieved was to improve the student's critical thinking disposition and skill in science for junior high school students. Meanwhile, the design of the book included layout, use of format, size and type of letters, pictures, tables, diagrams and argument maps.

3) Development of preliminary form of the product: Materials or information obtained in research and information collection stage were used to design the draft of the argument-based science textbook for junior high school. In addition, critical thinking disposition inventory was also developed. The critical thinking disposition inventory was developed based on the existing critical thinking disposition inventory. Meanwhile, the student's critical thinking skill was measured with a critical thinking skill test developed by the previous researchers (Sudria \& Redhana, 2013). This test has item validity of $0.127-0.708$ and reliability of 0.915 . On the other hand, the critical thinking disposition inventory contained statements related to critical spirit with five response options, i.e., strongly agree $($ score $=5)$, agree $($ score $=4)$, do not know (score $=3)$, do not agree $($ score $=2)$, and strongly disagree (score=1). This inventory was translated from the critical thinking inventory developed by Ricketts (2003).

Before it was tried out on a limited scale, the argument-based science textbook for junior high school and the critical thinking disposition inventory were validated first by experts. Their readability was tested by students. 1) Expert validation: the argument-based textbook for junior high school and the critical thinking disposition inventory were reviewed by three experts who had expertise in textbook development, argument, and critical thinking. The suggestions given by the experts were used to improve the textbook and the critical thinking inventory developed, 2) Readability test: the argument-based text book and critical thinking disposition inventory had been improved based on the suggestions from experts and their readability was tested by ten grade eight junior high school students. The purpose of the readability test was to know the students' understanding of the content of the text book, and the critical thinking inventory developed. The findings obtained from this readability test were used to improve the argument-based science textbook for junior high school and the critical thinking inventory.

Before it was used to measure the students' critical thinking, the critical thinking disposition inventory was tried out experimentally to determine its validity and reliability. This try- out used 97 students as the sample who came from three SMPN's in Bali Province (SMPN 1 Singaraja, SMPN 4 Sukasada, and SMPN 2 Singaraja). The selection of these SMP's was done by using cluster random sampling technique.

The product yielded in the first year was the draft of the argument-based science textbook for junior high school which had been validated by experts and a valid and reliable critical thinking disposition inventory and whose readability was tested and the valid and reliable critical thinking disposition inventory. In addition, a paper was also written which was presented at a national seminar.

The second year study, 4) Preliminary field testing: the argument-based science textbook was tried out (first try-out) at three SMP's in Bali Province, i.e., SMPN 1 Singaraja, SMPN 2 Singaraja, and SMPN 
4 Sukasada. The number of students involved in this limited try-out was 88 students: 22 studentsof class VIIA7 from SMPN 1 Singaraja, 30 students of class VIIA9 from SMPN 2 Singaraja, 36 students of class VIIA1 from SMPN 4 Singaraja. This try-out research on a limited scale used pretest-posttest one group design. The number of students involved in this second year research was 88 students. This limited tryout was aimed at finding out the effect of the argument-based science textbook for junior high school on the student's critical thinking disposition and skill. In addition, it was also aimed at finding qualitative findings, such as difficulties in understanding materials in the text book, the constraints faced in implementing the text book and the teachers' and students' opinions about the argument-based science text book for junior high school which they used in teaching.

5) Main product revision: Results obtained from the limited try-out were used to revise the text book developed and/ or the strategies of implementation. Based on the findings from the limited try-out, revision was done in the strategy of implementation, which improved the involvement of teachers in guiding the students in understanding arguments and argument maps. The product produced in the second year was the argument-based science textbook for junior high school that has been tried out on a limited scale. In addition, a paper was also written and presented at a national seminar and scientific article was ready to be published in Jurnal Ilmiah Pengajaran MIPA (Scientific Journal of Mathematics and Science Instruction).

The third year research, 6) Main field testing: After being revised based on the results from the limited try-out, this argument-based science textbook for junior high school was tried out on a large scale (main field testing) at three SMP's in Bali Province. This research used nonequivalent pretest-posttest control group design. 194 students were involved in this study. The control and experiment groups had 97 students respectively. The experiment group was taught by using the argument-based science textbook for junior high school, while the control group was taught by Buku Ajar SMP Kurikulum 2013 which was generally used by the science teachers in Bali Province. The aim of this try-out on a large scale was to find out the effectiveness of the argument-based science textbook for junior high school in improving the students critical thinking disposition and skill. In addition, the opinions from teachers and students about the argument-based science textbook for junior high school were collected through interview and questionnaire.

7) Operational product revision: Results obtained from the try-out on a large scale were used to improve the argument-based textbook for junior high school so that it can be effective in improving junior high school student's critical thinking disposition and skill. The product yielded in this year was the argument-based textbook for junior high school that had been tried out on a large scale. In addition, a scientific article was ready to be published in Jurnal Pendidikan IPA Indonesia (Journal of Indonesia's Science Education). an accredited scientific journal.

The technique for collecting data and the instrument used in this study were based on the type of data needed. Table 1 summaries the relation between data needed, data source, data collection technique and instrument used.

Table 1 Relation between Data Needed, Data Source, Data Collection Technique and Instrument Used in the Study

\begin{tabular}{|c|c|c|c|}
\hline Data needed & Data source & $\begin{array}{c}\text { Data collection } \\
\text { technique }\end{array}$ & Research instrument \\
\hline \multicolumn{4}{|l|}{ Literature study } \\
\hline Essential concepts & $\begin{array}{l}\text { Core competencies and } \\
\text { basic competencies } \\
\text { (Kurikulum 2013) }\end{array}$ & Document study & $\begin{array}{l}\text { Sheets for recording } \\
\text { documents }\end{array}$ \\
\hline List of concepts analysis & $\begin{array}{l}\text { Essential science } \\
\text { concepts }\end{array}$ & Document study & $\begin{array}{l}\text { Sheets for recording } \\
\text { documents }\end{array}$ \\
\hline $\begin{array}{l}\text { The critical thinking disposition } \\
\text { indicator }\end{array}$ & $\begin{array}{l}\text { Scientific journal and } \\
\text { textbooks }\end{array}$ & Document study & $\begin{array}{l}\text { Sheets for recording } \\
\text { documents }\end{array}$ \\
\hline $\begin{array}{l}\text { Theories and findings of } \\
\text { researches related to argument } \\
\text { and critical thinking }\end{array}$ & $\begin{array}{l}\text { Scientific Journal and } \\
\text { textbooks }\end{array}$ & Document study & $\begin{array}{l}\text { Sheets for recording } \\
\text { documents }\end{array}$ \\
\hline \multicolumn{4}{|l|}{ Field study } \\
\hline $\begin{array}{l}\text { Studies related to science } \\
\text { textbook used by the teachers }\end{array}$ & Science textbooks & Document study & $\begin{array}{l}\text { Sheets for recording } \\
\text { documents }\end{array}$ \\
\hline $\begin{array}{l}\text { Studies on the teaching } \\
\text { materials written and used by }\end{array}$ & Instructional materials & Document study & $\begin{array}{l}\text { Sheets for recording } \\
\text { documents }\end{array}$ \\
\hline
\end{tabular}




\begin{tabular}{|c|c|c|c|}
\hline Data needed & Data source & $\begin{array}{c}\text { Data collection } \\
\text { technique }\end{array}$ & Research instrument \\
\hline \multicolumn{4}{|l|}{ science teachers } \\
\hline $\begin{array}{l}\text { Studies on students } \\
\text { characteristics }\end{array}$ & Student & $\begin{array}{l}\text { Questionnaire } \\
\text { and interview }\end{array}$ & $\begin{array}{l}\text { Questionnaire and } \\
\text { interview guide }\end{array}$ \\
\hline $\begin{array}{l}\text { Studies on supporting facilities } \\
\text { for instruction }\end{array}$ & School facilities & Observation & Observation guide \\
\hline \multicolumn{4}{|l|}{ Expert Validation } \\
\hline $\begin{array}{l}\text { Content validation of the draft } \\
\text { of the argument- based science } \\
\text { textbook for junior high school } \\
\text { and critical thinking disposition } \\
\text { Readability test }\end{array}$ & Experts & $\begin{array}{l}\text { Document study } \\
\text { expert } \\
\text { discussion forum } \\
\text { (FGD) }\end{array}$ & Checklist \\
\hline $\begin{array}{l}\text { The readability of the draft of } \\
\text { the argument-based science } \\
\text { textbook for junior high school } \\
\text { and critical thinking disposition } \\
\text { inventory }\end{array}$ & Students & $\begin{array}{l}\text { Students and } \\
\text { researchers } \\
\text { discussion forum } \\
\text { (FGD) }\end{array}$ & Checklist \\
\hline \multicolumn{4}{|l|}{ Limited try-out } \\
\hline $\begin{array}{l}\text { Achievement in critical thinking } \\
\text { disposition and skill }\end{array}$ & $\begin{array}{l}\text { Scores for critical } \\
\text { thinking disposition } \\
\text { inventory and critical } \\
\text { thinking skill }\end{array}$ & $\begin{array}{l}\text { Test and } \\
\text { inventory }\end{array}$ & $\begin{array}{l}\text { Critical thinking } \\
\text { inventory nad critical } \\
\text { thinking skill }\end{array}$ \\
\hline $\begin{array}{l}\text { Students difficulty in } \\
\text { understanding the content of } \\
\text { the textbook and constraints } \\
\text { faced in implementing the text } \\
\text { book }\end{array}$ & Instructional process & Observation & Observation guide \\
\hline $\begin{array}{l}\text { Teachers' and students' } \\
\text { opinions about the argument } \\
\text { based science text book for } \\
\text { junior high school }\end{array}$ & Teachers students & $\begin{array}{l}\text { Interview and } \\
\text { questionnaire }\end{array}$ & $\begin{array}{l}\text { Interview guide and } \\
\text { questionnaire }\end{array}$ \\
\hline Try-out on a large scale & & & \\
\hline $\begin{array}{l}\text { The effectiveness of argument- } \\
\text { based science textbook for } \\
\text { junior high school }\end{array}$ & $\begin{array}{l}\text { Scores for disposition } \\
\text { and critical thinking } \\
\text { skill }\end{array}$ & $\begin{array}{l}\text { Test and } \\
\text { inventory }\end{array}$ & $\begin{array}{l}\text { Disposition inventory } \\
\text { and critical thinking } \\
\text { skill test }\end{array}$ \\
\hline $\begin{array}{l}\text { Teachers' and students' } \\
\text { opinions about the text book }\end{array}$ & Teachers and students & $\begin{array}{l}\text { Interview and } \\
\text { questionnaire }\end{array}$ & $\begin{array}{l}\text { Interview guide and } \\
\text { questionnaire }\end{array}$ \\
\hline
\end{tabular}

The techniques for analyzing data in this study consisted of 1) the technique for measuring Validity and reliability of the research instruments: Critical thinking disposition inventory was determined by product moment correlation. While the reliability of critical thinking disposition inventory was determined by Alpha Cronbach technique, 2) Technique used for analyzing the study results: the data collected in this study consisted of qualitative and quantitative data. The data at the research and information collection stage were qualitative data. Similarly, data obtained from the result of expert validation, reliability test, and students' difficulties in understanding the textbook materials, constraints in implementing the text book in the limited try- out and the try out on a large scale, and the teachers' opinions about the test book were qualitative data.

These data were analyzed descriptively. Meanwhile, the quantitative data were in the form of the scores from the pretest and posttest in the student's critical thinking disposition and the students' critical thinking skill from the limited try-out and the try-out on a large scale and the students' opinions about the argument-based science textbook for junior high school. The data in the form of the pretest and posttest of the inventory and student's critical thinking skill from the limited try-out were analyzed using descriptive statistics and pair-sample t-test at $5 \%$ level of significance. However, assumption tastings, consisting of normality testing and variance homogeneity testing were conducted first. On the other hand, the data in the form of scores for the pretest and the posttest of inventory and students' critical thinking skill from the try-out on a large scale were analyzed using descriptive analysis and multivariate covariance analysis at $5 \%$ level of significance. However, before that assumption tastings (consisting of normality testing, 
variance homogeneity testing, linearity testing, regression line slope homogeneity testing, variance covariance matrices homogeneity testing and multi collinearity testing were done first. These tests were done by using SPSS v.16 program.

\section{Result}

The covariate variable in this study was the students' prior knowledge (pretest scores). On the other hand, the independent variables in this study were science textbooks for junior high schools, consisting of two levels, Buku Ajar IPA SMP Kurikulum 2013 (Science Textbook for Junior High School According to 2013 Curriculum) and argument based science text book for junior high school. As the effect of independent variable a change occurred in the dependent variable. The dependent variable in this study consisted of student's critical thinking disposition and student's critical thinking skill. The results of descriptive analysis of the data are presented in Table 2.

Table 2. Mean, Standard Deviation, Student Critical Thinking Disposition and Students Critical Thinking Skill

\begin{tabular}{llrr}
\hline Test & Group & Mean & Standard deviation \\
\hline Pretest & Control & 39.369 & 8.884 \\
& Experiment & 39.804 & 9.218 \\
Critical thinking disposition & Control & 69.538 & 10.255 \\
& Experiment & 81.400 & 9.449 \\
Critical thinking skill & Control & 72.805 & 9.420 \\
& Experiment & 80.370 & 9.215 \\
\hline
\end{tabular}

Before hypothesis testing of multivariate covariance analysis was done, some assumptions had to be met first. The assumption test for multivariate covariance analysis consisted of normality, variance homogeneity, the homogeneity of variance covariance matrices, linearity, regression line slope homogeneity, and multi collinearity tests.

The normality test was intended for finding out the distribution of data in dependent variable whether normally distributed or not. The data distribution is normal if it is bell-shaped. Normality test is done to all the variables simultaneously the normality test can be done through univariate normality test. If univariate normality test in each variable meets the criterion, then the result of normality test will do too. The hypothesis that were tested were

$\mathrm{H}_{0}$ : sample comes from a normally distributed population

$\mathrm{H}_{\mathrm{a}}$ : sample does not come from a normalitydistributed population

The criterion for accepting or rejecting Ho is as follows. If the obtained sig (p) is greater than $\alpha(p$ $>\alpha$ ), then, Ho is accepted. Otherwise, Ho is rejected. The result of normality test is shown in Table 3.

Table 3. Result of Normality Test in Covariate Variable and Dependent Variable

\begin{tabular}{cccccccc}
\hline \multirow{2}{*}{ Variable } & \multirow{2}{*}{ Group } & \multicolumn{3}{c}{ Kolmogorov-Smirnov } & \multicolumn{3}{c}{ Shapiro-Wilk } \\
& & Statistic & Df & Sig. & Statistic & df & Sig. \\
\hline $\begin{array}{c}\text { Critical } \\
\text { thinking }\end{array}$ & control & 0.041 & 97 & 0.200 & 0.988 & 97 & 0.562 \\
disposition & & & & & & & \\
& Experiments & 0.071 & 97 & 0.200 & 0.978 & 97 & 0.103 \\
$\begin{array}{c}\text { Critical } \\
\text { thinking skill }\end{array}$ & control & 0.056 & 97 & 0.200 & 0.986 & 97 & 0.400 \\
& Experiments & 0.075 & 97 & 0.200 & 0.981 & 97 & 0.172 \\
\hline
\end{tabular}

Based on the data in Table 5.2, the value of sig. $\alpha$ (p) in each variable for the Kolmogorov-Smirnov statistic (sample size $>50$ ) is greater than $\alpha(005)$ then, Ho is accepted. Thus, it can be concluded that the sample comes from a normally distributed population. The variance homogeneity test is meant to find out intergroup variance equality in each dependent variable. The hypothesis tested were

$\mathrm{H}_{0}$ : the population variance is homogeneous

$\mathrm{H}_{\mathrm{a}}$ : the population variance is not homogeneous 
The criterion for accepting or rejecting Ho was as follows. If the value of sig. (p) obtained is greater than $\alpha(0.05)$, then Ho is accepted. Otherwise, Ho is rejected. The data of the testing of variance homogeneity is presented in Table 4.

Table 4. Results from Levine's Test for variance error similarity

\begin{tabular}{lccccc}
\hline & Variable & F & df1 & df2 & Sig. \\
\hline Critical disposition & & 0.092 & 1 & 192 & 0.762 \\
Critical Thinking Skill & 0.397 & 1 & 192 & 0.529 \\
\hline
\end{tabular}

Based on the data in Table 4, the obtained sig. (p) was greater than - $(0.05)$ for dependent variables, thus Ho was accepted. In other words, it can be concluded that the variance of the population is homogeneous or identical. The test of variance covariance matrices homogeneity was meant to find out whether the variance-covariance matrices of the dependent variables is homogeneous for the existing groups (independent variables). This test used Box's test. Box's text is a variance-covariance matrices test, i.e., the test of variance-covariance equality in the two dependent variables simultaneously.

$\mathrm{H}_{0}$ : The variance covariance matrices is homogeneous

$\mathrm{H}_{\mathrm{a}}$ : the variance covariance matrices is not homogeneous

The criterion for accepting or rejecting Ho is as follows. If sig. (p) is greater than $\alpha(0.05)$, then, Ho is accepted. Otherwise, Ho is rejected. The result of the testing of the variance covariance matrices is presented in Table 5.

Table 5. Result of the testing of variance covariance matrices homogeneity

\begin{tabular}{cc}
\hline Box's Test of Equality of Covariance Matrices & \\
\hline Box's M & 1.058 \\
F & 0.349 \\
df1 & 3 \\
df2 & $6,636.10^{6}$ \\
Sig. & $\mathbf{0 . 7 9 0}$ \\
\hline
\end{tabular}

Based on Table 5, the obtained sig. (p) is greater than $\alpha(0.05)$, thus $\mathrm{H}_{0}$ is accepted. Therefore, the variance covariance matricesare homogeneous. The linearity test was done to find out whether there was an effect of the covariate variables on the dependent variables. The hypotheses tested were

$\mathrm{H}_{0}$ : linear regression model

$\mathrm{H}_{\mathrm{a}}$ : nonlinear regression model

The criterion for accepting or rejecting of Ho is a follows. If the obtained sig. (p) in the aspect of deviation from linearity is greater than $\alpha(0.05)$, then $\mathrm{H}_{0}$ is accepted. Otherwise, $\mathrm{H}_{0}$ is rejected. The result of the linearity test is presented in Table 6.

Table 6. Results of the linearity test between covariateand dependent variables

\begin{tabular}{lllrrrrr}
\hline \multicolumn{1}{c}{ Interaction } & Group & Description & $\begin{array}{c}\text { Sum of } \\
\text { Squares }\end{array}$ & df & Mean Square & F & Sig. \\
\hline Critical & Between & (Combined) & 22219,256 & 157 & 141524 & 1.556 & 0.060 \\
thinking & Groups & Linearity & 5436,048 & 1 & 5436.048 & 59.771 & 0.000 \\
disposition & & Deviation from & 16783,208 & 156 & 107.585 & 1.183 & $\mathbf{0 . 2 8 3}$ \\
$*$ Pretest & & Linearity & & & & & \\
& Within Groups & 3274.121 & 36 & 90.948 & \\
Critical & Total & & 25493.377 & 193 & & \\
& Between & (Combined) & 18730.932 & 157 & 119.305 & 6.017 & 0000
\end{tabular}




\begin{tabular}{|c|c|c|c|c|c|c|c|}
\hline Interaction & Group & Description & $\begin{array}{c}\text { Sum of } \\
\text { Squares }\end{array}$ & df & Mean Square & $\mathbf{F}$ & Sig. \\
\hline \multirow{4}{*}{$\begin{array}{l}\text { thinking } \\
\text { Pretest }\end{array}$} & Groups & Linearity & 12882.507 & 1 & 12882.507 & 649.682 & 0.000 \\
\hline & & $\begin{array}{l}\text { Deviation from } \\
\text { Linearity }\end{array}$ & 5848.425 & 156 & 37.490 & 1.891 & 0.063 \\
\hline & \multicolumn{2}{|c|}{ Within Groups } & 713.842 & 36 & 19.829 & & \\
\hline & \multicolumn{2}{|l|}{ Total } & 19444.774 & 193 & & & \\
\hline
\end{tabular}

Table 6 shows that the obtained sig. (p) in the aspect of deviation from linearity is greater than $\alpha$ $(0.05)$ both for the effect of the covariate variable on critical thinking disposition and the effect of the covariate variable on critical thinking skill. Therefore, $\mathrm{H}_{0}$ is accepted. It can be concluded that linear regression model for the effect of the covariate variable on critical thinking disposition and the effect of the covariate variable on critical thinking skill can be accepted. The regression line slope homogeneity test is meant to find out whether the slope of the regression line of the covariate variable and the dependent variable for the control and experiment groups in each of the dependent variables is homogeneous or not. The hypotheses that were tested were

$\mathrm{H}_{0}: \mathrm{B}_{1}=\mathrm{B}_{2}$ (intergroup homogenous regression coefficient)

$H_{a}: B_{1} \neq B_{2}$ ( the intergroup regression coefficient is not homogeneous.

The criterion for accepting or rejecting Ho is as follows. If the obtained sig. (p) in the aspect of the *Pretest group is greater than $\alpha$,then $\mathrm{H}_{0}$ is accepted. Otherwise, $\mathrm{HO}$ is rejected. The result of regression line slope homogeneity is shown in Table 7.

Table 7 Results of regression line slope homogeneity

\begin{tabular}{llrrrrr}
\hline \multicolumn{1}{c}{ Source } & \multicolumn{1}{c}{ Dependent Variable } & $\begin{array}{c}\text { Type III Sum } \\
\text { of Squares }\end{array}$ & df & Mean Square & F & Sig. \\
\hline Corrected & critical thinking disposition & 12075.358 & 3 & 4025.119 & 56.996 & 0.000 \\
Model & critical thinking skill & 15383.014 & 3 & 5127.671 & 239.861 & 0.000 \\
Intercept & critical thinking disposition & 26513.657 & 1 & 26513.657 & 375.435 & 0.000 \\
& critical thinking skill & 16140.729 & 1 & 16140.729 & 755.027 & 0.000 \\
Group & critical thinking disposition & 770.113 & 1 & 770.113 & 10.905 & 0.001 \\
& critical thinking skill & 174.601 & 1 & 174.601 & 8.167 & 0.005 \\
Pretest & critical thinking disposition & 5195.049 & 1 & 5195.049 & 73.562 & 0.000 \\
& critical thinking skill & 12603.467 & 1 & 12603.467 & 589.562 & 0.000 \\
group & $*$ critical thinking disposition & 101.368 & 1 & 101.368 & 1.435 & $\mathbf{0 . 2 3 2}$ \\
Pretest & critical thinking skill & 4.788 & 1 & 4.788 & 0.224 & $\mathbf{0 . 6 3 7}$ \\
Error & critical thinking disposition & 13418.020 & 190 & 70.621 & & \\
& critical thinking skill & 4061.760 & 190 & 21.378 & & \\
Total & critical thinking disposition & 1130448.289 & 194 & & & \\
& critical thinking skill & 1157389.891 & 194 & & & \\
Corrected & critical thinking disposition & 25493.377 & 193 & & & \\
Total & critical thinking skill & 19444.774 & 193 & & & \\
\hline
\end{tabular}

From the data in Table 7 it appears that sig. (p) of the interaction between group and pretest for the dependent variable of critical thinking disposition and critical thinking skill were 0.232 and 0.637 respectively. Both of these values of sig. (p) are greaterthan 0.05 respectively. This means that Ho is accepted. Therefore, the slope of regression line both for critical thinking disposition and critical thinking skill is homogeneous. Multi collinearity test is an intervariable regression test. The hypotheses tested were 
$\mathrm{H}_{0}$ : there is alinear relation between dependent variables.

$\mathrm{H}_{\mathrm{a}}$ : there is no linear relation between dependent variables.

The criterion for accepting or rejecting Ho is as follows. If sig. (p) is less than $\alpha(0.05)$, then $\mathrm{H}_{0}$ is accepted. Otherwise, then $\mathrm{H}_{0}$ is rejected. We can also find out the multi collinearityof the correlation coefficient ( $\mathrm{r}$ ). If the obtained $\mathrm{r}$ is between 0.3 and 0.8 , then we cannot detect any multi collinearity. The result of the test of multi collinearity is shown in Table 8.

Table 8 Result of the test of multicollinearity

\begin{tabular}{llrr}
\hline & Variable Statistic & \multicolumn{1}{c}{$\begin{array}{c}\text { critical } \\
\text { thinking skill }\end{array}$} & $\begin{array}{c}\text { critical thinking } \\
\text { disposition }\end{array}$ \\
\hline Pearson Correlation & critical thinking skill & 1.000 & $\mathbf{0 . 5 8 6}$ \\
& critical thinking disposition & $\mathbf{0 . 5 8 6}$ & 1.000 \\
Sig. (1-tailed) & critical thinking skill & $\cdot$ & $\mathbf{0 . 0 0 0}$ \\
N & critical thinking disposition & $\mathbf{0 . 0 0 0}$ & 194 \\
& critical thinking skill & 194 & 194 \\
\hline
\end{tabular}

Based on the data in Table 8, the obtained sig. (p) is less than $\alpha(0.05)$, thus $\mathrm{H}_{0}$ is accepted. This means that there is a linear relation between critical thinking disposition and critical thinking skill. On the other hand, the obtained $r$ value is 0.586 . This means that no multi collinearity is detected between the dependent variables, that is between the variablesof critical thinking disposition and critical thinking skill. From all the assumption tests done above, all the assumption tests support the follow-up of the multivariate covariance analysis test. In other words, the covariance multivariate analysis can be followed up. After all of the assumption tests were carried out and their results support the follow-up to the multivariate covariance analysis test, then the hypotheses that were formulated in this study were as follows.

a. $\mathrm{H}_{0}$ : There is no effect of the science textbook for SMP on critical thinking disposition and critical thinking skill simultaneously after the covariate variable is controlled.

$\mathrm{H}_{a}$ : There is an effect of the science textbook for SMP on critical thinking disposition and critical thinking skill simultaneously after the covariate variable is controlled.

b. $\mathrm{H}_{0}$ : There is no effect of the science textbook for junior secondary school on critical thinking disposition after the covariate variable is controlled.

Ha: There is an effect of the science textbook for junior secondary school on critical thinking disposition and critical thinking skill after the covariate variable is controlled.

c. Ho: There is no effectof the science textbook for junior high school after the covariate variable is controlled.

$\mathrm{H}_{\mathrm{a}}$ : There is an effect of science textbook for junior high school on critical thinking skill after the covariate variable is controlled.

The criterion for accepting and rejecting Ho is as follows. If the obtained sig. (p) in the aspect of the group for Pillai's Trace, Wilks' Lambda, Hoteling's Trace, and Roy's Largest are less than $\alpha(0.05)$, then $\mathrm{H}_{0}$ is rejected. Otherwise, Ho is accepted. The result of multivariate covariance analysis is presented in Table 9.

Table 9 Resultof multivariate covariance analysis

\begin{tabular}{|c|c|c|c|c|c|c|c|c|}
\hline & Effect & Value & $\mathbf{F}$ & $\begin{array}{l}\text { Hypothesi } \\
\text { s df } \\
\end{array}$ & Error df & Sig. & $\begin{array}{l}\text { Nonaccent. } \\
\text { Parameter }\end{array}$ & $\begin{array}{c}\text { Observed } \\
\text { Power }\end{array}$ \\
\hline \multirow[t]{4}{*}{ Intercep } & Pillai's Trace & 346 & 522.6 & 2.000 & & 0.000 & 1045.171 & 1.000 \\
\hline & Wilks' Lambda & 0.154 & 522.6 & 2.000 & 190.000 & 0.000 & 1045.171 & 1.000 \\
\hline & Hoteling's Trace & 5.501 & 522.6 & 2.000 & 190.000 & 0.000 & 1045.171 & 1.000 \\
\hline & $\begin{array}{l}\text { Roy's Largest } \\
\text { Root }\end{array}$ & 5.5 & 522.6 & 2.000 & 190.000 & 0.000 & 1045.171 & 1.000 \\
\hline \multirow[t]{2}{*}{ Group } & Pillai's Trace & 0.502 & 95.945 & 2.000 & 190 & 0000 & 1045.171 & 1.000 \\
\hline & Wilks' Lambda & 0.498 & 95.945 & 2.000 & 190.000 & 0.000 & 1045.171 & 1.000 \\
\hline
\end{tabular}




\begin{tabular}{llrrrrrrr} 
& Hoteling's Trace & 1.010 & 95.945 & 2.000 & 190.000 & 0.000 & 1045.171 & 1.000 \\
Roy's Largest & 1.010 & 95.945 & 2.000 & 190.000 & 0.000 & 1045,171 & 1.000 \\
Root & & & & & & & 1.000 \\
Pretest & Pillai's Trace & 0.768 & 315.0 & 2.000 & 190.000 & 0.000 & 1045.171 & 1.000 \\
& Wilks' Lambda & .232 & 315,0 & 2.000 & 190.000 & 0.000 & 1045.171 & 1.000 \\
& Hoteling's Trace & 3,316 & 315,0 & 2.000 & 190.000 & 0.000 & 1045.171 & 1.000 \\
\hline Roy's Largest & 3,316 & 315,0 & 2.000 & 190.000 & 0.000 & 1045.171 & \\
Root & & & & & & &
\end{tabular}

Table 9 shows that the obtained sig. (p) for the four Pillai's Traces, Wilks' Lambdas, Hoteling's Traces, and Roy's Largest in the aspect of group are less than $\alpha(0.05)$. This means that Ho is rejected or Ha is accepted. Therefore, it can be concluded that there is an effect of the argument-based science textbook for Junior High School Students on critical thinking disposition and critical thinking skill simultaneouslyafter the covariate variable is controlled (the testing of hypothesis point a). The next test was done to find the effect of the science textbook for junior high school on critical thinking disposition and critical thinking skill separately or partially after the covariate variable is controlled (the testing of hypotheses points $\mathrm{b}$ and $\mathrm{c}$ ). The results are presented in Table 10.

Table 10 Resultsof the test of the effect of Science Textbook for Junior High School on critical thinking disposition and criticalthinking separately.

\begin{tabular}{|c|c|c|c|c|c|c|c|c|}
\hline Source & $\begin{array}{c}\text { Dependent } \\
\text { Variable }\end{array}$ & $\begin{array}{c}\text { Type III } \\
\text { Sum of } \\
\text { Squares }\end{array}$ & df & Mean Square & $\mathbf{F}$ & Sig. & $\begin{array}{l}\text { Nonaccent. } \\
\text { Parameter }\end{array}$ & $\begin{array}{c}\text { Observed } \\
\text { Power }\end{array}$ \\
\hline \multirow[t]{2}{*}{$\begin{array}{l}\text { Correcte } \\
\text { d Model }\end{array}$} & $\begin{array}{l}\text { critical thinking } \\
\text { disposition }\end{array}$ & 11973.990 & 2 & 5986.995 & 84.583 & 0.000 & 169.167 & 1.000 \\
\hline & $\begin{array}{l}\text { critical thinking } \\
\text { skill }\end{array}$ & 15378.226 & 2 & 7689.113 & 361.147 & 0.000 & 722.293 & 1.000 \\
\hline \multirow[t]{2}{*}{$\begin{array}{l}\text { Intercep } \\
\mathrm{t}\end{array}$} & $\begin{array}{l}\text { critical thinking } \\
\text { disposition }\end{array}$ & 26639.043 & 1 & 26639.043 & 376.353 & 0.000 & 376.353 & 1.000 \\
\hline & $\begin{array}{l}\text { critical thinking } \\
\text { skill }\end{array}$ & 16172.895 & 1 & 16172.895 & 759.618 & 0.000 & 759.618 & 1.000 \\
\hline \multirow[t]{2}{*}{ Group } & $\begin{array}{l}\text { critical thinking } \\
\text { disposition }\end{array}$ & 6537.941 & 1 & 6537.941 & 92.367 & 0.000 & 92.367 & 1.000 \\
\hline & $\begin{array}{l}\text { critical thinking } \\
\text { skill }\end{array}$ & 2495.719 & 1 & 2495.719 & 117.220 & 0.000 & 117.220 & 1.000 \\
\hline \multirow[t]{2}{*}{ Pretest } & $\begin{array}{l}\text { critical thinking } \\
\text { disposition }\end{array}$ & 5148.666 & 1 & 5148.666 & 72.740 & 0.000 & 72.740 & 1.000 \\
\hline & $\begin{array}{l}\text { critical thinking } \\
\text { skill }\end{array}$ & 12602.495 & 1 & 12602.495 & 591.921 & 0.000 & 591.921 & 1.000 \\
\hline \multirow[t]{2}{*}{ Error } & $\begin{array}{l}\text { critical thinking } \\
\text { disposition }\end{array}$ & 13519.388 & 191 & 70.782 & & & & \\
\hline & $\begin{array}{l}\text { critical thinking } \\
\text { skill }\end{array}$ & 4066,548 & 191 & 21.291 & & & & \\
\hline \multirow[t]{2}{*}{ Total } & $\begin{array}{l}\text { critical thinking } \\
\text { disposition }\end{array}$ & $\begin{array}{r}1130448.2 \\
89\end{array}$ & 194 & & & & & \\
\hline & $\begin{array}{l}\text { critical thinking } \\
\text { skill }\end{array}$ & $\begin{array}{r}1157389.8 \\
91\end{array}$ & 194 & & & & & \\
\hline \multirow[t]{2}{*}{$\begin{array}{l}\text { Correcte } \\
\text { d Total }\end{array}$} & $\begin{array}{l}\text { critical thinking } \\
\text { disposition }\end{array}$ & 25493.377 & 193 & & & & & \\
\hline & $\begin{array}{l}\text { critical thinking } \\
\text { skill }\end{array}$ & 19444.774 & 193 & & & & & \\
\hline
\end{tabular}


Table 10 shows that in the aspect of group it seems that the science textbook for Junior High School has an effect on critical thinking disposition and critical thinking skill separately. This can be seen from the value of sig. (p) which is less than 0.05 , both for critical thinking disposition and critical thinking skill. Then mean difference can be seen in Table 11 to know which textbook is better in improving critical thinking disposition and critical thinking skill separately.

Table 11 Meandifference between control group and experiment group

\begin{tabular}{|c|c|c|c|c|c|c|c|}
\hline \multirow{2}{*}{$\begin{array}{l}\text { Dependent } \\
\text { Variable }\end{array}$} & \multirow{2}{*}{ (I) group } & \multirow{2}{*}{ (J) group } & \multirow{2}{*}{$\begin{array}{c}\text { Mean } \\
\text { Difference } \\
\text { (I-J) }\end{array}$} & \multirow{2}{*}{$\begin{array}{l}\text { Std. } \\
\text { Error }\end{array}$} & \multirow{2}{*}{ Sig. ${ }^{a}$} & \multicolumn{2}{|c|}{$\begin{array}{c}95 \% \text { Confidence } \\
\text { Interval for Difference }\end{array}$} \\
\hline & & & & & & Lower Bound & $\begin{array}{l}\text { Upper } \\
\text { Bound }\end{array}$ \\
\hline \multirow{2}{*}{$\begin{array}{l}\text { critical thinking } \\
\text { disposition }\end{array}$} & Control & experiment & $-11.614^{*}$ & 1.208 & 0.000 & -13.997 & -9.230 \\
\hline & Experiment & control & $11.614^{*}$ & 1.208 & 0.000 & 9.230 & 13.997 \\
\hline \multirow{2}{*}{$\begin{array}{l}\text { critical } \\
\text { skill }\end{array}$} & Control & experiment & $-7.176^{*}$ & 0.663 & 0.000 & -8.483 & -5.868 \\
\hline & experiment & control & $7.176^{*}$ & 0.663 & 0.000 & 5.868 & 8.483 \\
\hline
\end{tabular}

Based on estimated marginal means

*. The mean difference is significant at the .05 level.

a. Adjustment for multiple comparisons: Least Significant Difference (equivalent to no adjustments).

Table 11 shows the mean difference between the control group and the experiment group is significant (see the sign *). The mean of the experiment group is higher than that of control group. In other words, the argument-based science textbook for junior high school is better than Buku Ajar SMP Kurikulum 2013 (Science Textbook for Junior High School according to the 2013 Curriculum) in improving critical thinking disposition and critical thinking skill.

The students' opinions about the argument-based science textbook for junior high school were collected through a questionnaire. The description about students' opinions can be seen in Table 12 .

Table 12 The Recap of Percentages of the Students Opinions About the Argument Based Text Book for Junior High School

\begin{tabular}{|c|c|c|c|c|c|c|}
\hline \multirow{2}{*}{ No. } & \multirow{2}{*}{ Statement } & \multicolumn{5}{|c|}{ Percentages (\%) } \\
\hline & & 1 & 2 & 3 & 4 & 5 \\
\hline 1. & $\begin{array}{l}\text { The practicum activity can lead me to understand the } \\
\text { science materials presented in this science text book for } \\
\text { junior high school }\end{array}$ & - & - & - & 46.11 & 53.89 \\
\hline 2. & The language used in this the book is easy to understand & - & - & 12.54 & 42.78 & 44.68 \\
\hline 3. & $\begin{array}{l}\text { Pictures, Tables, or diagrams used in the textbook help } \\
\text { me to understand science materials. }\end{array}$ & - & - & 10.65 & 33.34 & 56.01 \\
\hline 4. & $\begin{array}{l}\text { The arguments used to present science materials in the } \\
\text { text book help me understand science materials. }\end{array}$ & - & - & 9.32 & 53.65 & 37.03 \\
\hline 5. & $\begin{array}{l}\text { I tried to find claims and premises/proofs/reasons } \\
\text { presented in the arguments. }\end{array}$ & - & - & 16.87 & 32.98 & 50.15 \\
\hline 6. & $\begin{array}{l}\text { Argument maps help me understand the arguments } \\
\text { presented in the text book. }\end{array}$ & - & - & 23.71 & 25.66 & 50.63 \\
\hline 7. & $\begin{array}{l}\text { The arguments used to present science materials in the } \\
\text { textbook can help me train critical thinking skill. }\end{array}$ & - & - & 18.39 & 36.94 & 44.67 \\
\hline 8. & $\begin{array}{l}\text { Examples presented in this text book are relevant to } \\
\text { daily life. }\end{array}$ & - & - & 8.78 & 37.51 & 53.71 \\
\hline 9. & $\begin{array}{l}\text { The coverage of science materials in the text book is } \\
\text { wide and deep. }\end{array}$ & - & - & 16.22 & 56.76 & 27.02 \\
\hline 10. & $\begin{array}{l}\text { The practices and solutions to problems in the this } \\
\text { textbook help me understand science materials. }\end{array}$ & - & - & 2.67 & 53.67 & 43.66 \\
\hline 11. & $\begin{array}{l}\text { There are reviews in this textbook which challenge me } \\
\text { to think critically. }\end{array}$ & - & - & 12.52 & 28.46 & 59.02 \\
\hline 12. & $\begin{array}{l}\text { There are implementation problems that challenge me } \\
\text { to apply the science concepts that i have learned. }\end{array}$ & - & - & 9.64 & 31.37 & 58.99 \\
\hline
\end{tabular}


13. There are reflections which condition me to thank God Almighty that everything in this world is His creation.

14. There are summaries which make me easy to find concept comprehensively.

15. There are reflections that help me to do self-evaluation about my understanding of the content of the text book.

Based on the data in Table 12, generally, the argument based science text book for junior high school is very useful for the students in understanding science materials more comprehensively and deeply. This is caused by the argument presented which are more and more complex. While, science teachers evaluated that this argument based science textbook for junior high school can make it easy for them to guide the students during the teaching process. In addition, they thought that this argument based science text book for junior high school is very good for developing students critical disposition and critical thinking skill.

The results of this study showed that the science text book for junior high school is more effective to improve the students critical thinking disposition and critical thinking skill compared to Buku Ajar Kurikulum 2013. Critical thinking disposition is the spirit to think critically (Ennis, 1985). Disposition also mean someone's inclination to used critical thinking skill. Meanwhile, American Philosophical Association (in Jeweled\& Thompson, 2014) states that critical thinking disposition is the habit that produces a control decision making for a problem or a choice faced in a personal and professional situation. According toJeweled and Thompson (2014), critical thinking disposition is statement to develop a good critical thinking skill. Without an inclination to use critical thinking skill that one has, one cannot reach the solution of a problem faced or to make an appropriate decision. A person who has critical thinking skill does not necessarily have critical thinking disposition. Thus, in order for critical thinking skill to be able to use to solve a problem or to make a responsible decision there is a need for a motivation or a tendency to use critical thinking skill.

The improvement of the student's critical thinking disposition and critical thinking skill was cause by the fact that the argument based science text book for junior high school uses the language of reasoning. It means that the presentation of science material in each paragraph uses of the language of reasoning or argument. An argument contains list of statement which form a claimed or a conclusion and the other statement are in the form of premise or reason or proof (Lau \& Chan, 2009). Still according to Lau \& Chan (2009), to be able to think critically, students should be able to identify, construct, and evaluate an argument. An argument consists of a claim and premises. A claim is a conclusion for the major part of the discourse. On the other hand, a premise is a support for a claim. This support can be in the form of reason, proof, facts, etc. In short, the premise functions to strengthen or clarify the claim or conclusion. Basically, an argument can consist of one or more claims and is supported by one or more premises. The simplest argument is an argument which consist of a claim and a premise.

The science textbook for junior high school, besides consisting of an argumentative presentation of science materials, it also contains an argument map. An argument map is a box and line diagram which shows relations between claims and premises. The boxes represent claims and premises, while lines with arrows connect premises and claims. This relation in a paragraph can be seen implicitly or explicitly in the form of conjunction. The indicators of conjunction for claims, among others, are "so that..., therefore..., as the result..., finally..., which proves that..., can be concluded that..., shows that..., and should...,". On the other hand, the indicator of conjunction for premise is shown by words or phrases, such as "because..., for..., from the fact that..., the reason is..., first..., second..., and third...," (Fisher, 2004). The presence of the indicators, both for claims and premises will help students to identify which are the claims and which are the premises of argument.

In writing argument maps, every sentence in a paragraph is numbered using Arabic number. From sentences which are contained in a paragraph, the students identify which sentence is a claim and which sentences are premises and which sentences do not belong to any of them or only give additional explanation. Tawdry (2004) states that students have to be able to articulate and evaluate arguments. The students then make boxes for claim and then boxes for premises. Finally, students draw lines connecting premises to claims with arrows. The following is a paragraph about science materials that has presented argumentatively and an argument map which represents an argumentation in the presentation of science materials.

On the other hand, since alcohol has many weaknesses, quicksilver is often used as the liquid to fill in a thermometer (1) ...This is because quicksilver has some advantages compared to alcohol (2). First quicksilver can absorb heat of an object which will be measured so that the temperature of the quicksilver is the same as the temperature of the object measured (3). Second, quicksilver can be used to measure 
temperature from the lowest to the highest degree because it has the freezing temperature of $-39^{\circ} \mathrm{C}$ and the melting temperature of $357^{\circ} \mathrm{C}[4]$. Third, quicksilver does not wet the tube so that the measurement is more careful [5]. Fourth, the expansion of quicksilver is regular or linear to the increase in temperature [6]. Fifth, quicksilver is easier to see since it can reflect light [7]. The argument map for the science material above is as follows

\section{Argument map:}

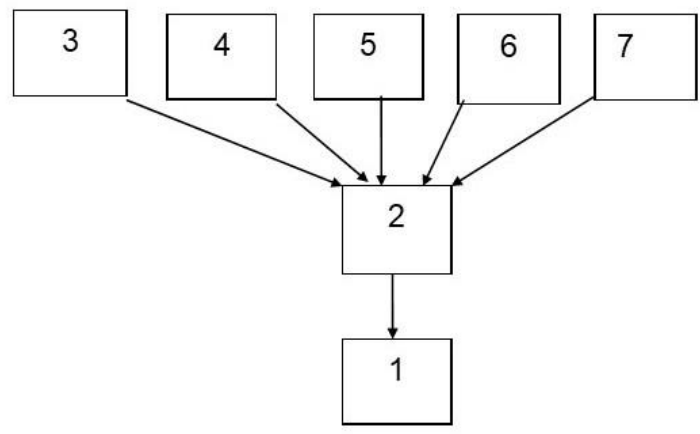

Figure 2 an example of argument map

The transformation of science materials presentation of the paragraph above into an argument map will simplify the argument presented. As the result, students will find it easy to understand an argument if it is presented in the form of argumentation and diagram. This is because the language of reasoning use is more structured. Students can identify claims and premises quickly since the presence of claims and premises are shown by the indicators of claims and premises explicitly. The ease in identifying claims and premises helps students to understand arguments and thus, the students understand science materials easily. This is supported by the study conducted by Zohar and Nemet (2002) that integrating arguments into an instruction can improve performance, both in knowledge and argument. Cross et al. (2008) also support Zohar and Nemet (2002) that learning arguments can strengthen concept understanding, enabling students to get new ideas which can extend knowledge, and eliminating misconceptions that the students experience. On the other hand, Marttunena et al. (2005) believe that argument in instructional process can help students to improve critical thinking skill.

The results of studies show that the presentation of materials aided by diagrams or pictures facilitate the students to learn the materials. Presentation of material using diagrams or pictures help the students who have visual learning style very much. (Gilakjani, 2012). If more students have visual learning style, then presentation in the form of pictures or diagram will be easily understood by the students than those in other forms, such as in auditory and kinesthetic forms.

Studies to investigate the effectiveness of argument maps in improving learning achievement and critical thinking skill have been reported by some researchers. Redhana (2012b) report that the use of argument map can increase chemistry learning achievement. Redhana (2009; 2010a; 2010b; 2011; 2012b; 2012c) also report that the use of argument maps is very effective to increase student's critical thinking skill. Meanwhile, van Gelder (2003) reports that argument maps can improve student's ability to articulate, understand, and communicate reasoning so that it can spur critical thinking disposition and critical thinking skill.

According to Oswald (2007), the advantage of making argument maps are (1) argument presentation becomes very efficient, in which argument maps can condense some pages of a complex explanation into a single map ; (2) The display of argument structure can be presented clearly, in which arguments are translated into a map which is the very good form of critical thinking skill; and (3) each copremise can be shown explicitly in which argument maps will spur the students to identify assumptions which are not stated and asked proof for each component of the argument. In short, argument maps are a transparent and effective way to present arguments and to make the operation of critical thinking skill more clearly so that producing pastern critical thinking skill development.

From the results obtained above it seems that the students who have an opportunity to be trained to make arguments maps can develop their critical thinking skill. There is a correlation between argument ad critical thinking skill (Jimenez-Aleixandre, Rodriguez, \& Duschl, 2000; Inch \& Warnick, 2006). Indratin (2010) states that there is a correlation between logical thinking and student's ability to understand arguments. The higher the student's logical ability, the higher their skill in argument will be. The findings 
in this study are in line with the previous findings (van Gelder, 2003; Twardy, 2004; Ostwald, 2007; Bassham et al., 2008; Lau \& Chan, 2009). Specifically, van Gelder (2003) states that an argument map can improve student's ability to articulate, understand, and communicate arguments so that it can spur critical thinking skill. According to Ostwald (2007), argument map is transparent an efective for presenting arguments and making critical thinking skill operation become clearer so that it produces a faster critical thinking skill development. Meanwhile, Basshamet al. (2008) state that critical thinking skill is closely related to reason, that is to identify reason, to evaluate reason, and to give reason. This is the essence of argument (critical thinking skill). Improvement in critical thinking skill encourages students to master science materials better. Therefore, students learning achievement increase. Low students, argument skill becomes one of the causes of students' low critical thinking skill (Hasnunidah et al., 2015). Learning to compose an argument is needed very badly in the learning process. This will have students in improving critical thinking skill.

The argument based science text book for junior high school which is implemented in teaching gives a different characteristic to the model of learning implemented. Although different textbooks used the same instructional model, the implementation of the learning model in the textbook developed is slightly different. This is caused by the fact that textbook also has an effect on the student's thinking. In the argument-based science textbook for junior high school, students are given more encouragement to use critical thinking in understanding science materials through the presentation the material argumentatively and the use of argument maps. The results are in line with the previous findings (Kalelioglu \& Gulbahar, 2014). Kalelioglu and Gulbahar (2014) report that the use of Socrates Seminar can improve students critical thinking disposition effectively.

\section{Conclusions and Recommendations}

Based on the results obtained in this study it can be concluded that there is a significant effect of the science textbook for junior high school on student's critical thinking disposition and critical thinking skill both simultaneously and partially or individually. Based on the means difference test, the argument-based science textbook for junior high school is better than Buku Ajar IPA SMP Kurikulum 2013 in increasing students critical thinking disposition and critical thinking skill, both simultaneously and partially. Based on the results obtained in this study it can be recommended to the science teachers that they use the argument-based science textbook for junior high school to improve students critical thinking disposition and critical thinking skill.

\section{References}

Borg, W. R. \& Gall, M. D. 1989. Educational research: An introduction. $5^{\text {th }}$ Ed. New York: Longman, Inc.

Cross, D., Taasoobshirazi, G., Hendrick, S., \& Hickey, D. (2008). Argumentation a strategy for improving achievement and revealing scientific identities. International Journal of Science Education, 30(6), 837-861.

Crumbley, D. L. \& Smith, M. (2000). Using short stories to teach critical thinking and communication skills to tax students. Accounting Education. 9(3), 291-296.

Facione, P. A., Facione, N., \& Giancarlo, C. (2001). California critical thinking disposition inventory: CCTDI inventory manual. Millbrae, CA: California Academic Press.

Gilakjani, A. P. (2012). Visual, auditory, kinaesthetic learning styles and their impacts on english language teaching. Journal of Studies in Education, 2(1), 104-113.

Hasnunidah, N., Susilo, H., Irawati, M., H., \& Sutomo, H. (2015). Argument-driven inquiry with scaffolding as the development strategies of argumentation and critical thinking skills of students in lampung, Indonesia. American Journal of Educational Research, 3(9).

Inch, S.E., \& Warnick, B. (2006). Critical Thinking And Comunication, the use of reason in argument. Pearson Education.

Indratin, M. (2010). Hubungan antara kemampuan berpikir logis dan minat menulis dengan keterampilan menulis argumentasi. [Online]. Available at https://core.ac.uk/download/files/478/12350940.pdf. [3 Maret 2016].

International Association for the Evaluation of Educational Achievement. (2011). Trends in International Mathematics and Science Study (TIMSS), 2011. [Online]. Availble at http://www.eqao.com/pdf_e/12/TIMSS_Ontario_Report_2011.pdf. [18 April 2013]. 
Jimenez-Aleixandre, M., P., Rodriguez, A., B., \& Duschl, R., A. (2000). Doing the lesson or doing science: argument in high school genetics. Science Education, 84, 757-792.

Kemendikbud. (2013). IPA untuk SMP/MTs Kelas VII. Jakarta: Kemendikbud.

Ladyshewsky, R. K. (2006). Peer coaching: A contructivist methodology for enhancing critical thinking in postgraduate business education. Higher Education Research \& Development. 25(1), 67-84.

Lau, J. \& Chan, J. (2009). Argument mapping. [Online]. Available at http://philosophy.hku.hk/ think/ arg/arg.php. [15 Februari 2009].

Organisation for Economic Co-operation and Development. (2012). PISA 2012results: Executive summary. [Online]. http://www.oecd.org/pisa/pisaproducts/46619703.pdf. [18 April 2014].

Pemerhati Guru. (2013). Prinsip-prinsip bahan ajar untuk guru. [Online]. Tersedia: http://panduanguru.com/prinsip-prinsip-bahan-ajar-untuk-guru/. [18 April 2014].

Puspitorini, R., Prodjosantoso, A. K., Subali, B., \& Jumadi, J. (2014, October 9). Penggunaan Media Komik Dalam Pembelajaran Ipa Untuk Meningkatkan Motivasi Dan Hasil Belajar Kognitif Dan Afektif. Cakrawala Pendidikan. Retrieved from http://journal.uny.ac.id/index.php/cp/article/view/2385

Redhana, I W. \& Liliasari. (2008a). Efektivitas program pembelajaran critical thinking skill pada topik termokimia. Proseding Seminar Nasional Kimia dan Pendidikan Kimia (UNS). 22 Nopember 2008.

Redhana, I W. \& Liliasari. (2008b). Program for critical thinking skill teaching and learning: excellences and problems in its implementation. Proceeding of the Second International on Science Education (UPI). October 18, 2008.

Redhana, I W. \& Liliasari. (2008c). Program pembelajaran critical thinking skill pada topik laju reaksi untuk siswa SMA. Forum Kependidikan. 27(2), 103-112.

Redhana, I W. \& Liliasari. (2009a). Peningkatan critical thinking skill siswa melalui program pembelajaran berbasis masalah terbimbing pada topik termokimia. Proseding Seminar Nasional Pendidikan (UNILA). 24 Januari 2009.

Redhana, I W. \& Liliasari. (2009b). Studi efektivitas program pembelajaran berbasis masalah terbimbing pada topik laju reaksi. Jurnal Penelitian Pendidikan IPA. 3(2), 101-110.

Redhana, I W. (2009). Application of argument mapping-based learning model to improve students' critical thinking skills in thermochemistry topic. Proceeding of the The $3^{\text {rd }}$ International Seminar on Science Education, Science Education Program, Graduate School, Indonesia University of Education, October 17.

Redhana, I W. (2010a). Pengaruh model pembelajaran berbasis peta argumen terhadap critical thinking skill siswa pada topik laju reaksi. Jurnal Pendidikan dan Pengajaran, 42(2), 141-148.

Redhana, I W. (2010b). The development of argument-map-based-chemistry workbook of themochemistry topic. Proceeding of the The $4^{\text {th }}$ International Seminar on Science Education, Science Education Program, Graduate School, Indonesia University of Education, October 30.

Redhana, I W. (2012a). Model pembelajaran berbasis masalah dan pertanyaan Socratik untuk meningkatkan critical thinking skill siswa. Cakrawala Pendidikan, XXXI(3), 351-365.

Redhana, I W. (2012b). Pengaruh model pembelajaran berbasis peta argumen terhadap hasil belajar kimia siswa SMA. Makalah disajikan pada Seminar Nasional FMIPA Universitas Pendidikan Ganesha, 13 Oktober.

Redhana, I W. (2012c). Pengaruh model pembelajaran berbasis peta argumen terhadap critical thinking skill dan motivasi belajar siswa pada mata pelajaran kimia SMA. Laporan penelitian (tidak dipublikasikan). Singaraja: Universitas Pendidikan Ganesha.

Redhana, I W., Sudiatmika, A. A. I A. R., \& Artawan, I K. (2011). Pengembangan Perangkat Pembelajaran Berbasis Masalah dan Pertanyaan Socratik untuk Meningkatkan critical thinking skill Siswa pada Mata Pelajaran IPA di SMP. Laporan penelitian (tidak dipublikasikan). Singaraja: Universitas Pendidikan Ganesha.

Redhana, I. W. (2011). Efektivitas buku kerja kimia berbasis peta argumen dalam meningkatkan critical thinking skill siswa. Jurnal Pendidikan Kimia Indonesia. 1(1), 18-27.

Ricketts, J. C. (2003). The efficacy of leadership development, critical thinking dispositions, and student academic performance on the critical thinking skills of selected youth leaders. Dissertation (unpublished). Florida: University of Florida.

Rizal. (2014). Pengaruh pembelajaran inkuiri terbimbing dengan mind map terhadap keterampilan proses sains dan hasil belajar IPA. Jurnal Pendidikan Sains, 2(4), 159-165. Retrieved from http://journal.um.ac.id/index.php/j ps

Rusnadi, D. P. P. N. W. A. (2013, July 5). Penerapan Model Pembelajaran Kooperatif Tipe Team Games Tournament Untuk Meningkatkan Kemampuan Berpikir Kritis Dan Hasil Belajar Ipa. MIMBAR PGSD. Retrieved from http://ejournal.undiksha.ac.id/inde x.php/JJPGSD/article/view/881 
Selamat, I N., Redhana, I W. \& Suardana, I N. (2009). Pengembangan buku kerja kimia berbasis peta argumen menggunakan konteks budaya lokal untuk meningkatkan critical thinking skill siswa SMA. Laporan penelitian (tidak dipublikasikan). Singaraja: Universitas Pendidikan Ganesha.

Sidi, I. D. (2003). Menuju masyarakat belajar: Menggagas paradigma baru pendidikan. Ciputat: Logos Wacana Ilmu.

Soegiranto,M.A.(2010). Acuan Penulisan Bahan Ajar Dalam Bentuk Modul. Pokja Kurikulum dan Supervisi Pusat Pengembangan Madrasah Kementrian Agama Provinsi Nusa Tenggara Timur

Sudria, I B. N. \& Redhana, I W. (2013). Pengembangan tes critical thinking skill. Paper presented at Seminar Nasional SeNaRi I Lembaga Penelitian Undiksha, 21-22 November.

Sukerni, Putu. 2014. Pengembangan Buku Ajar Pendidikan Ipa Kelas Iv Semester I Sd No. 4 Kaliuntu Dengan Model Dick and Carey. Jurnal Pendidikan Indonesia Universitas Pendidikan Ganesha Volume 3 Nomor 1.

Susiani, K., Dantes, N., \& Tika, N. (2013, May 10). Pengaruh Model Pembelajaran Quantum Terhadap Kecerdasan Sosio-emosional Dan Prestasi Belajar Ipa Siswa Kelas V Sd Di Banyuning. Jurnal Pendidikan Dasar. Retrieved from http://119.252.161.254/ejournal/index.php/jurnal_pendas/a rticle/view/525

Trisnani, I., Hasyim, A., \& Djasmi, S. (2015, January 12). Evaluasi Program Pembelajaran Ipa. Jurnal Teknologi Informasi Komunikasi Pendidikan. Retrieved from http://jurnal.fkip.unila.ac.id/index.p $\mathrm{hp} / \mathrm{JTP} /$ article/view/4778

The Jakarta Post (2011).Indonesia ranks 124th in 2011 Human Development Index. [Online]. Tersedia: http://www.thejakartapost.com/news. [18 April 2013].

Twardy, C. R. (2004). Argument maps improve critical thinking. [Online]. Tersedia: http://www.csse.monash.edu.au. [8 September 2006].

van Gelder, T. (2001). The Reason!Project. The Skeptic.21(2). 1-6.

Woodfield, B. F., Andrus, M. B., Andersen, T., Miller, J., Simmons, B., \& Stanger, R. (2005). The virtual chemlab: A realistic and sophisticated simulation of organic synthesis and organic qualitative analysis. Journal of Chemical Education. 82(11), 1728-1735

Marttunena, M., Leena, L., Lia, L., \& Kristie, L. (2005). Argumentation skill as prerequisites for collaborative learning among Finnish, French, and English secondary school student. Educational Research and Evaluation, 11(4), 365-384.

Widiana, I Wayan. 2016. Pengembangan Asesmen Proyek Dalam Pembelajaran IPA Di Sekolah Dasar. Jurnal Pendidikan Indonesia Vol 5 No 2.

Zohar, A., \& Nemet, F. (2002). Fostering students' knowledge and argumentation skills through dilemmas in human genetics. Journal of Research 